\title{
The restoration of a Canadian naval ensign
}

\section{Captain Norman Jolin, RCN Retired}

Ce document retrace l'histoire des pavillons portés par les navires de guerre canadiens depuis 1911, peu après la création de la Marine royale $d u$ Canada, et donne en contexte les pratiques des marines nationales d'autres pays. La Marine a perdu son pavillon naval en 1965 avec l'intégration et l'unification des Forces armées canadiennes. Ce document présente de nouvelles sources archivales sur les efforts depuis lors pour restaurer le pavillon, notamment la récente initiative, acceptée plus tôt cette année.

As part of the celebrations surrounding the centennial of the Canadian navy in 2010, the Government of Canada precipitated a number of naval heritage initiatives such as the restoration of the executive curl and the "royal" designation of the Royal Canadian Navy (RCN) as a distinctive command. ${ }^{1}$ With those in effect, a return to a distinctive Canadian naval ensign is clearly in line with Government intent regarding heritage issues.

As with any change to historical practices, there will always be differing opinions as to what should, or should not, be done. Notwithstanding, the leadership of the Royal Canadian Navy decided to embark on a course to return to the well-established international practice of differentiating warships from other nationally flagged vessels by adopting a distinctive naval ensign.

With this in mind, I offer the following synopsis of the history of this initiative; and to assist the wide range of readers, I will address as well some of the popular myths surrounding flags and naval ensigns, in an objective, not subjective, narrative that tells a uniquely Canadian story.

1 Notwithstanding the restoration of the "royal" designation to the Royal Canadian Navy $(\mathrm{RCN})$ and Royal Canadian Air Force (RCAF), this did not mean a return to separate services, but rather they remain separate "Commands" within the unified Canadian Armed Forces; the Canadian Army, like its British counterpart, is not considered a "royal" force, but rather that designation is reserved for its arms and services. See John R. Grodzinski, "What's in a Name? The Royal Canadian Navy, the Canadian Army and the Royal Canadian Air Force," http://blog.thecanadianencyclopedia.com/blog/posts/what $\%$ E2\%80\%99s-in-a-namethe-royal-canadian-navy-the-canadian-army-and-the-royal-canadian-air-force/, accessed 12 June 2013.

The Northern Mariner/le marin du nord, XXIII No. 3, (July 2013), 267-286 


\section{Terminology and definitions pertaining to naval flags at sea}

- An ensign is "a flag, especially a military or naval one indicating nationality."

- A jack commonly describes "a small version of a national flag flown at the bow of a vessel in harbour."

- A pennant is "a tapering flag on a ship, especially one flown at the masthead of a vessel in commission."

- An ensign, jack or pennant is "worn" or "flown" in a vessel.

- The primary purpose of any ensign at sea, under international law, is to identify the nationality of the ship - the word itself derives from the Latin insignia or badge or mark "that which identifies." It is the most important flag flown by any vessel at sea, the only one which is absolutely required.

- The term warship means "a ship belonging to the naval forces of a State and bearing the external marks distinguishing warships of its nationality, under the command of an officer duly commissioned by the government and whose name appears in the Navy List, and manned by a crew who are under regular naval discipline."

- A suit of colours is worn by Her Majesty's ships in commission and "comprises a White Ensign, Jack (national flag) and a White Masthead Pennant. These flags are the formal acknowledgement of the national character, sovereignty and status of the ship in which they are flown."

\section{So what is a naval ensign?}

First and foremost, it is necessary to understand what a naval ensign is, as it is often called a "White Ensign" based on the British model-the British call it a white ensign because white is the predominant colour of the flag, with the Red Ensign being used for merchant ships and the Blue Ensign being for non-warship government vessels (as will be elaborated below, Canada being a member of the Empire and Commonwealth has followed this tradition). The reason the British naval ensign is white is because the more senior in colour ensign (red) was being used by British merchant ships and it was simply easier to have the Royal Navy (RN) adopt a white ensign (the attribution as an honour to Nelson as a ViceAdmiral of the White at Trafalgar is erroneous). Moreover, white was readily distinguishable from flags of the more traditional belligerents of the time (such as the French tricolour). Thus,

2 Definitions, unless otherwise indicated, are from the Concise Oxford English Dictionary, 11 th Edition (Oxford University Press, 2004), as adopted for use by the Canadian Armed Forces.

3 United Nations Convention on the Law of the Sea (UNCLOS I), "Convention of the High Seas," Article 8 (2.). The treaty was signed 29 April 1958 and entered into force 30 September 1962.

4 Naval Flags and Ensigns-A Note by the Naval Staff Directorate (UK, Version 1), p.8, at: http://www.luxe-motor-kei.co.uk/documents/NavalFlagsandEnsigns.pdf, accessed on 18 August 2012. 
while not every naval ensign in the world is white, a great many are, because the nations have (for whatever reason) adopted an internationally accepted British developed practice.

To quote the British Admiralty Memorandum No. 397 (9 September 1931), "The White Ensign is nothing else but the national colours of a ship of war in commission." An authoritative Canadian source similarly notes that an ensign is "The national flag of a country adapted for use on board ship."6 Because a naval ensign represents the national colours of the nation's warships, and under international law warships on the high seas have complete immunity from the jurisdiction of any State other than the Flag State, ${ }^{7}$ there are some implicit obligations that a sovereign nation must observe. Specifically, international law recognizes that every vessel afloat has a national character, and places duties on flag states to regulate and restrict the legitimate use of flags that indicate national character.

\section{So what ensigns and jacks have Canadian warships flown?}

When the Canadian Naval Service was established in 1910 (and

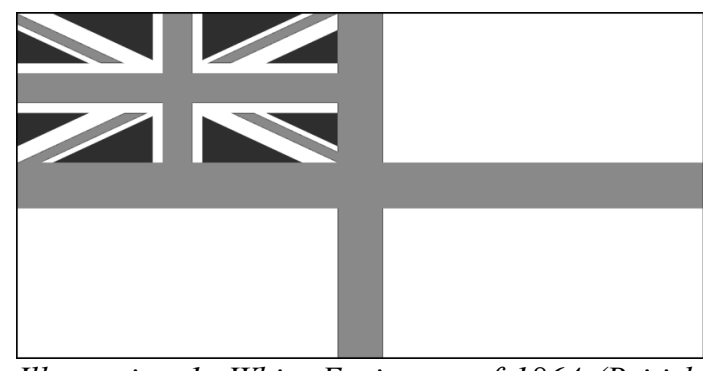

Illustration 1: White Ensign as of 1864 (British naval ensign.) Blue (darker) and red on white.

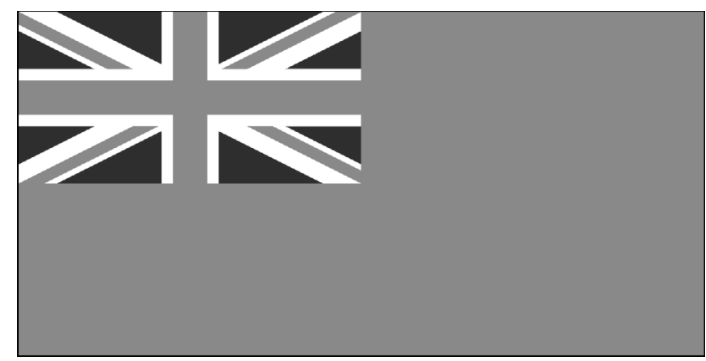

Illustration 2: Red Ensign as of 1864 (British merchant marine ensign.)

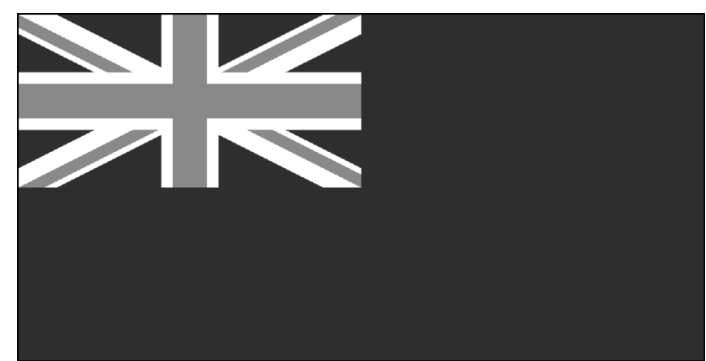

Illustration 3: Blue Ensign as of 1864 (British government ensign.)

became the RCN as of 19 August 1911), Canadian warships flew the Blue Ensign at the stern and the Union Flag as a jack at the bow "as was the custom for all other dominion government vessels."

5 Ibid.

6 Francis J. Dunphar and Joseph H. Harper, Old Colours Never Die (Ottawa: Service Publications, 1992).

7 UNCLOS I. "Convention of the High Seas," Article 8 (1).

8 Johnston, Rawling, Gimblett and Macfarlane, The Seabound Coast: The Official History of the Royal Canadian Navy, Volume 1, 1867-1939 (Toronto: Dundurn, 2010), p.175. Johnston et al, p.20, also note the "quasi-naval" status of the Fisheries Protection Service (FPS), out of which the Naval Service developed, in part symbolized by the suit of colours worn by FPS vessels:

By convention, all ships of the department flew the blue ensign with the Canadian coat of arms in the fly, but the fisheries cruisers were granted the additional distinction, under 
war outside Canadian waters" became a sticking point as to what ensign Canadian warships flew, because the control of foreign policy for the British Empire resided in Westminster until 1931. The proposal by Governor-General Lord Grey for a Canadianized white ensign (with the Cross of St George surmounted by a green maple leaf) was not addressed and and the ensign remained unchanged from that of 1864 (Illustration 1) $;^{9}$ instead the authority for the RCN to use the British White Ensign was an Order-in-Council which resulted from an agreement at the Imperial Conference of 1911: ${ }^{10}$

All ships and vessels of the Royal Canadian Navy shall fly at the stern the White Ensign as the symbol of the authority of the Crown, and at the Jack Staff the distinctive flag of the Dominion of Canada, such distinctive flag being the Blue Ensign with the arms of the Dominion inset in the fly. The White Pendant will be flown at the Masthead. ${ }^{11}$

This Order-in-Council set the direction for the suit of colours worn by His/Her

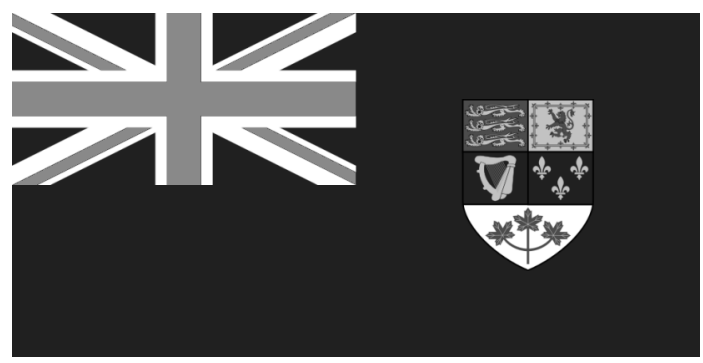

Illustration 4: Naval Jack (1957 version) as approved for HMC Ships. (The escutcheon saw minor changes from the 1911 and 1922 versions.) Majesty's Canadian (HMC) ships for the next 54 years.

\section{A Suit of Colours for HMC ships-16 December 1911}

This practice did not fundamentally change until 1965 as the $\mathrm{RCN}$, in both peace and war, continued using the British White Ensign and the Canadian Blue Jack up until the adoption of the distinctive Canadian maple leaf flag.

special warrant from the Admiralty, "of wearing the 'whiplash' [commissioning] pennant which is the distinguishing mark of a man-of-war."

9 The issue is discussed in Johnston et al, The Seabound Coast, pp.175-181.

10 Prior to the decision of the 1911 Imperial Conference and the subsequent promulgation of Order-in-Council PC 2843, there was no clarity as to what ensign and jack a Canadian warship should fly. Moreover, there were only two commissioned ships in the Canadian Naval Service, separated by over 4000 kilometers, and both were commanded by Royal Navy officers. Photographic evidence shows HMCS Niobe on the East Coast flying the white ensign and Union flag as a jack in February 1911 (Illustration 9), whereas HMCS Rainbow, on the West Coast, is seen flying the blue ensign with the Canadian Coat of Arms inset in the fly as both the ensign and the jack.

11 The authority for HMC ships to wear the British white ensign is Canadian Order-in-Council PC 2843 of 16 December 1911, published in the Canada Gazette on 30 December 1911. As background, the basis for the Order-in-Council is the 1911 Imperial Conference at Cd. 57462, No.1 "Memorandum of Conferences, between the British Admiralty and Representatives of the Dominion of Canada and the Commonwealth of Australia", Minutes of Proceedings of the Imperial Conference, 1911. A précis of this document can be found in excerpts from the 1911 Imperial Conference in: Gilbert Norman Tucker, The Naval Service of Canada, Its Official History: Origins and Early Years. Volume I (Ottawa: King's Printer, 1952), p.167 and The Seabound Coast, pp.179-181. 


\section{So what was Canada's national flag?}

It is noteworthy that until Canada formally adopted a national flag in 1965 it did not officially have a national flag; in fact, the official status of the red ensign was really only clarified in 1945: "The House of Commons was informed

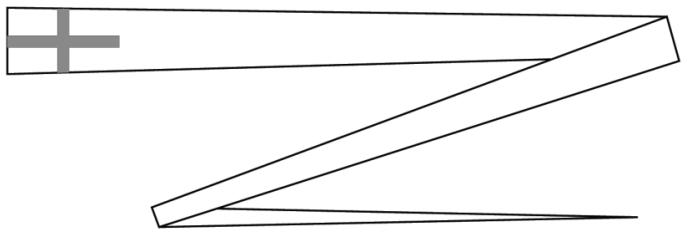

Illustration 5: Commissioning pennant as approved for HMC Ships (1911); red on white. on October 1, 1945, that: The Red Ensign is being flown from the Tower of the Houses of Parliament under authority of Order-in-Council, P.C. 5888, passed September 5, 1945. ..."12 The Order-in-Council contained these provisions:

That until such time as action is taken by parliament for the formal adoption of a national flag, it is desirable to authorize the flying of the Canadian Red Ensign on federal government buildings within as well as without Canada, and to remove any doubt as to the propriety of flying the Canadian Red Ensign wherever place or occasion may make it desirable to fly a distinctive Canadian flag. Nothing herein shall be deemed to alter in any way the provisions now in force with respect to the flying of the Blue Ensign with the Shield of the coat of Arms of Canada in the fly on Canadian naval vessels and other government vessels, nor with respect to the flying of the Canadian Red Ensign on Canadian Merchant vessels.

The order-in-council stopped short of declaring the red ensign the national flag of Canada, and instead gave it a provisional status "until such time as action is taken by parliament for the formal adoption of a national flag." 13

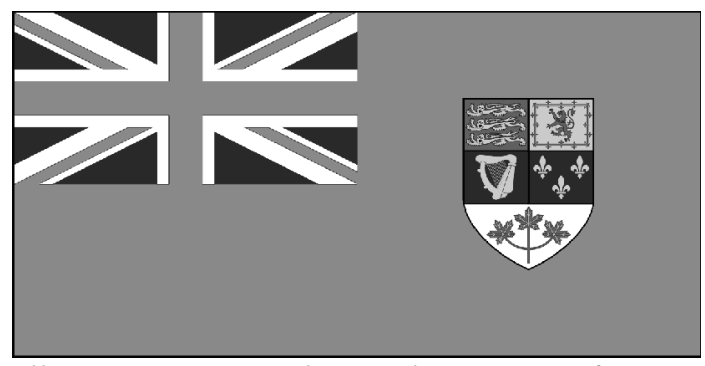

Illustration 6: Canadian Red Ensign as of 1957.

In truth, the Canadian flag was the British Royal Union flag, ${ }^{14}$ which is a flag, but not an ensign per se, and which has been incorporated into the canton of all British ensigns since 1707 (under the provisions of the British Treaty of Union of 1707). The current British Union flag is flown around the world representing wider British interests and historical

12 Alistair B. Fraser, The Flags of Canada (1998), Chap IV_-"The Canadian Ensigns" at: http://fraser.cc/FlagsCan/index.html, accessed on 18 August 2012. Ibid.

14 "...be informed that the Union Flag is the National Flag of Canada as of all other parts of His Majesty's dominions, and may be flown on land by all British subjects...," Lewis Harcourt (Secretary of State for the Colonies, London, 1911), quoted in Fraser, The Flags of Canada, Chap III-“The Royal Union Flag," at: http://fraser.cc/FlagsCan/Nation/Union .html, accessed 18 August 2012. See also: "The British Union Jack was the national flag of the entire British Empire including all of the Dominions until well after the Second World War," at http://www.atlasofbritempire.com/Dominions.html, accessed on 13 June 2013. 
connections $^{15}$ (and interestingly is referred to colloquially as "the Union Jack" from its use as such in $\mathrm{RN}$ vessels).

During this period, the British White (naval) Ensign was unchanged; however, the Canadian Blue Jack underwent the same changes as the Blue Ensign: the four-province badge was

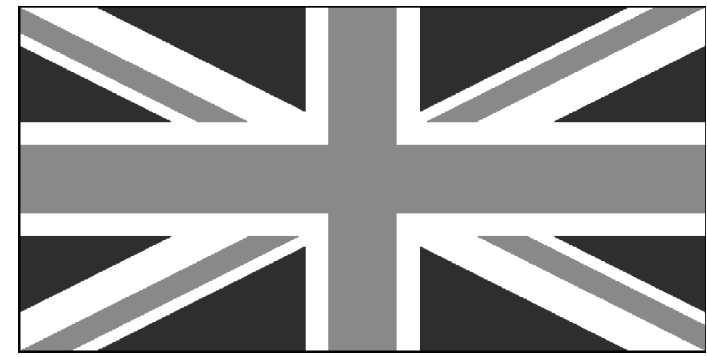

Illustration 7: Royal Union Flag as of 1801. used on the fly until 1922; thereafter the shield of the Canadian arms was used. The maple leaves on that shield changed from green to red soon after 1957. In naval vessels, the Canadian Blue Jack was the same flag as the Canadian Blue Ensign flown on other governmental vessels. ${ }^{16}$ In warships, this blue jack was always one size smaller than the white ensign that flew at the stern. Authority to wear the White Ensign and Blue Ensign in HMC ships and shore establishments was defined in KRCN and later QRCN (King's / Queen's Regulations and Orders for the Royal Canadian Navy). ${ }^{17}$

In 1965, in response to a Royal Proclamation, the official national flag of Canada (maple leaf flag) became the ship's ensign. ${ }^{18}$ Technically a flag is not an ensign, and the decision to fly the national flag as an ensign was a result of government direction to all Government of Canada institutions to ceremoniously change flags at 17:00 GMT on 15 February 1965 to the new maple leaf flag. The CANAVGEN of 31 December 1964 directed:

The new Canadian Flag will be flown effective the date to be set by proclamation of HM The Queen... Effective date of proclamation, the new Canadian flag will be flown by the Canadian Armed Forces in place of the present Canadian Red and Blue ensigns and the service ensigns wherever these flags are now flown or displayed including DND buildings, the ensign and jack in HMC ships and naval auxiliary vessels, all commissioned RCN shore establishments, HMC Dockyards and detached units which are not commissioned ... ${ }^{19}$

15 Naval Flags and Ensigns-A Note by the Naval Staff Directorate, p.6.

16 Fraser, The Flags of Canada, Chap VI, "The Flags of National Defence," at: http:// fraser.cc/FlagsCan/Nation/NatDefence.html, accessed 18 August 2012.

17 QRCN (BRCN 101, 1952, AL5), Volume I, Articles 62.38 and 62.39.

18 The design of the new Canadian flag was passed by a majority vote in the House of Commons on 15 December1964 and the Senate two days later. The Queen of Canada proclaimed the new flag on 28 January 1965 and it was inaugurated on 15 February 1965 at an official ceremony held on Parliament Hill in Ottawa.

19 CANAVGEN $321311800 Z$ DEC 64-New Canadian Flag. This "Canadian Naval General" message was promulgated pursuant to discussions at Defence Council $133^{\text {rd }}$ meeting held 30 December 1964: "ITEM VII Service Ensign (Confidential) Decisions 17. It was decided that: a. Subject to confirmation following further discussion by the Minister, it was proposed that: a. the new National Flag be flown in place of the Red Ensign and the Service Ensigns." This 

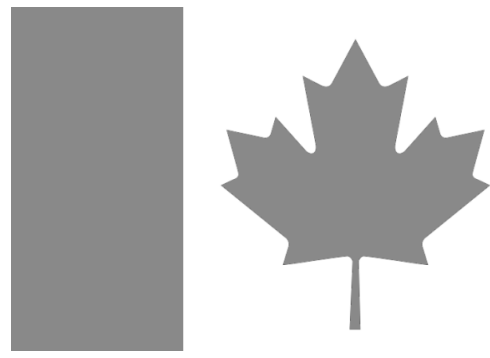

Illustration 8: Canadian national flag as of 15 February 1965.
Finally, on 11 February 1965, Order-in-Council 1965-250 directed the retirement of the White Ensign from service in the RCN, effective 15 February 1965, by cancelling PC 2843 of 16 December $1911 .^{20}$

In keeping with established Commonwealth practices, the national flag is normally flown as a jack, and so was the maple leaf flag from 1965 until $1968 .^{21}$

\section{Whither a Canadian naval ensign?}

In reviewing the record of Cabinet Decisions surrounding the adoption of the new national flag in 1965, it is clear that Cabinet allowed for a separate "special Ensign" in December 1964. Specifically, the Cabinet Decision of 23 December 1964 states:

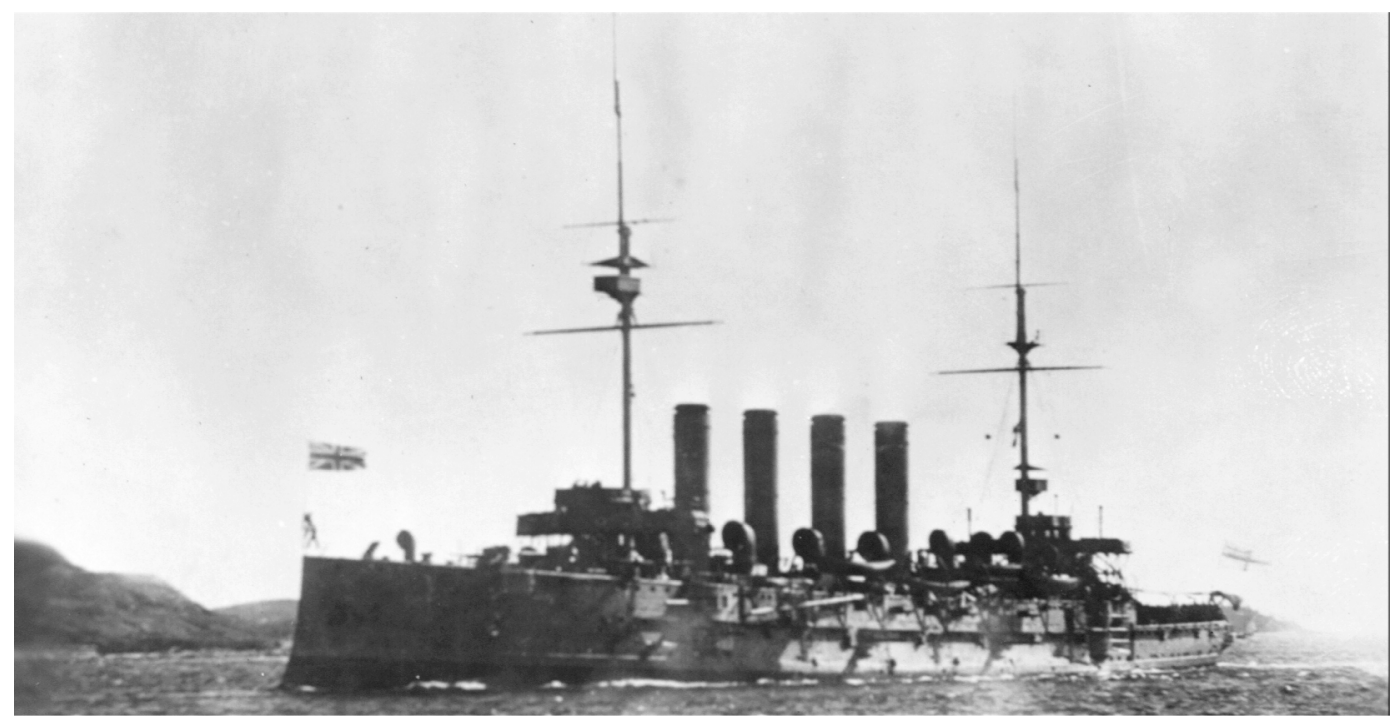

Illustration 9: HMS Niobe entering Halifax Harbour 21 October 1910 (RCN photo HS-6530).

became the subsequent authority for the CANAVGEN. Unless otherwise indicated, all primary source references are held on Directorate of History \& Heritage (DHH), document collection 97/23, file 43, Insignia, Badges, Flags and Colours, General, 1965.

20 1145-A vol. 2 (DC) 9 September 1966 - Minutes of Parliamentary Returns "White ensign--RCN".

21 The subsequent PC 1965-515, 24 March 1965, specifically directed Canadian flagged vessels to fly the new national flag, referring to vessels registered in Canada who are subject to the Canada Shipping Act and specifically highlighting those government vessels permitted to wear the blue ensign. This can be the cause of some confusion as, prior to 15 February 1965, HMC ships wore the Canadian blue ensign as a jack and not as an ensign. 
"(f) agreed that the minister of national defence would submit to the prime minister designs for an ensign for the armed services, to be patterned on the new Canadian flag and that the question whether a special ensign for the services would be desirable should be considered further thereafter." 22

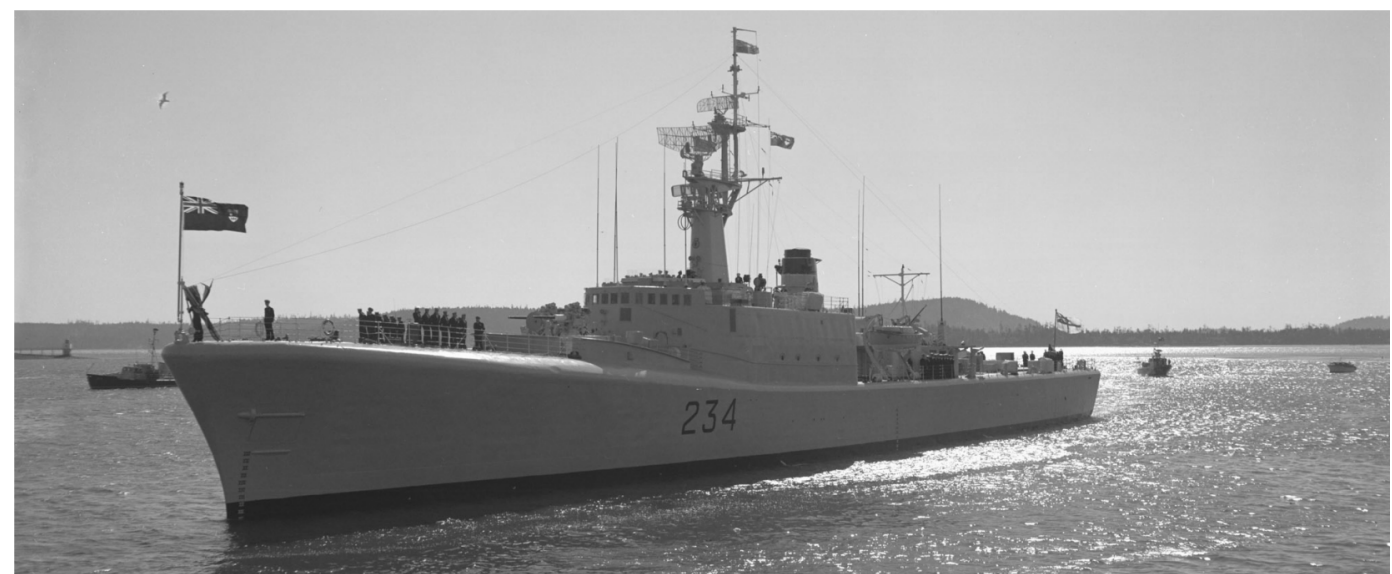

Illustration 10: HMCS Assiniboine entering Nanaimo Harbour in 1959 with HM The Queen embarked (RCN photo EKS-570).

Subsequent discussion on the flag issue by the Defence Council on 30 December 1964 - which was introduced by the Chief of Personnel (CP, Vice-Admiral Kenneth Dyer, see discussion below) - showed proposed examples of RCN and RCAF service ensigns. The ensuing discussion made it clear that while the army would fly the new Canadian flag in place of both the Union Flag and the Canadian Red Ensign, there was agreement that "consideration must be given to the need for a Canadian Forces ensign as it is possible that individual service ensigns may not be authorized." In addition to the decision to have the new national flag flown in place of service ensigns, the Defence Council decided that the "question of new Service ensign or ensigns would be considered at a later date," with the chief of personnel assigned as the action officer. ${ }^{23}$

At this point it is worth mentioning that less than five months previously all three service staffs had been abolished and a chief of the defence staff (CDS) had been appointed as the head of all Canada's military forces, backed by a general headquarters that was integrated and restructured to reflect functional commands. "Functional" described a command that was non-geographic, beyond any particular element or traditional arm. In Canadian Forces Headquarters (CFHQ), the aspiration was that all staffing would be carried out regardless of service affiliation, and during the transition phase to a fully unified Armed Force, the senior serving naval officer (under the new construct, the CP, Vice-Admiral Dyer), was appointed as the principal naval adviser to advise on specific matters dealing with naval issues. In short, in 1965 there was no head of navy as we know it today, neither was there as yet a Maritime Command, and most importantly there was no longer a dedicated naval staff.

22 Record of Cabinet Decision-Meeting of December 23rd 1964-The Flag.

23 Personnel Branch Defence Council Extract-Item VII Service Ensign (Confidential) dated 31December 1964. 
Accepting that the chief of personnel was a naval officer and that both Cabinet and the Defence Council had acknowledged the potential for a new service ensign(s) incorporating the new national flag, why did a Canadian naval ensign initiative not progress further? As the action officer, the $\mathrm{CP}$ sought advice from his staff as to the way forward vis-à-vis new ensign(s) patterned on the new Canadian flag. Reporting to $\mathrm{CP}$ was the director of ceremonial (DC), who as an Army officer did not see a requirement for a service ensign, "as it would serve no useful purpose either from the point of view of tradition or allegiance." He candidly admitted, however, that his position was influenced by the fact that "the Army has never flown service ensigns," and acknowledged the RCN and RCAF may disagree with his opinion "probably with every good reason." 24 Significantly, DC advice did not address the internationally recognized unique status a naval ensign bestows on a warship. Moreover, the follow-on staffing by Director General Administration (DGA) - an Air Force officer-supported the DC position and recommended "that the idea of a single Service ensign be dropped for the present." $\mathrm{He}$ also opined there "is strong consensus that no action should be taken to develop a Service ensign... it is very doubtful that a single ensign which would be generally acceptable would be introduced at present." ${ }^{25}$ Again his recommendation failed to address the unique status of a naval ensign in identifying warships.

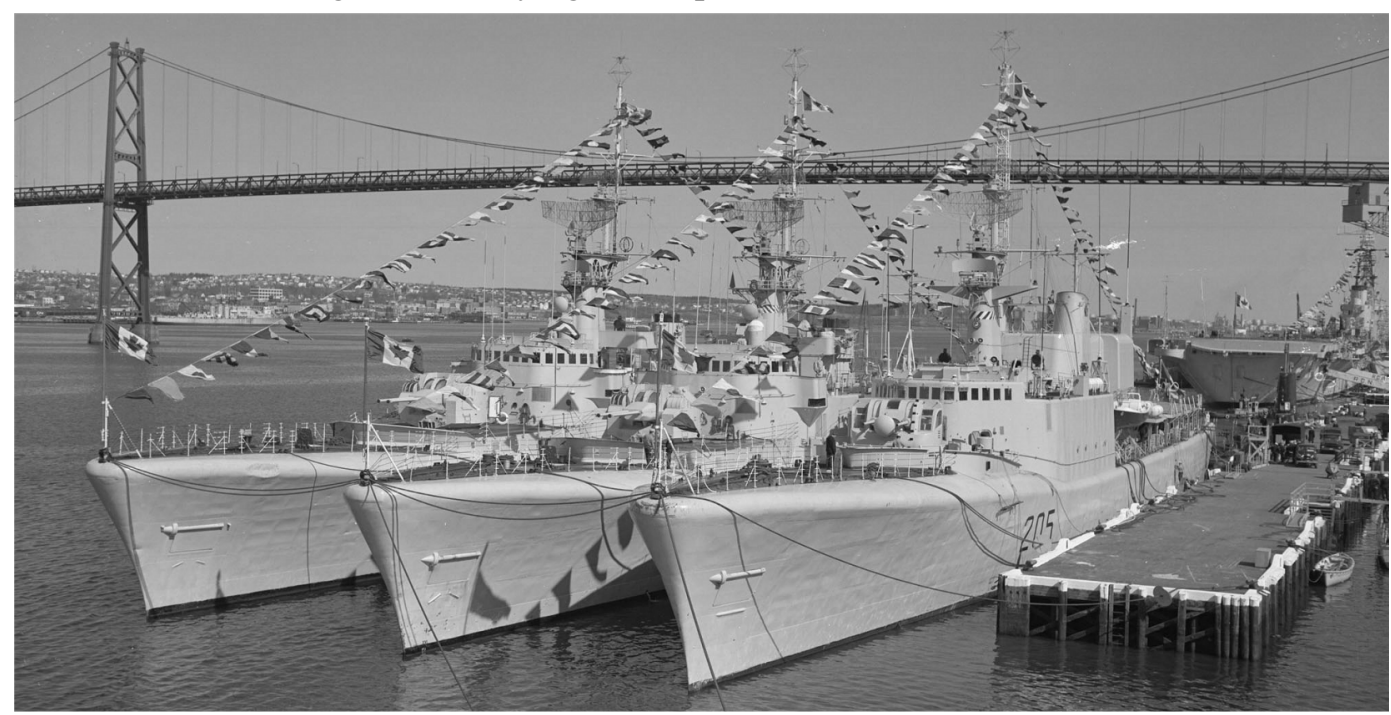

Illustration 11: Halifax circa 1965 - from left to right, the destroyer-escorts HMC Ships Restigouche, Gatineau and St. Laurent, the British conventional submarine HMS Acheron and the light fleet aircraft carrier HMCS Bonaventure alongside in Halifax Harbour. (RCN photo EKS-1826).

Anecdotal and some documentary evidence ${ }^{26}$ suggests the Minister of National Defence (MND), the Honourable Paul T. Hellyer, was unsupportive of separate ensigns beyond the national flag - whether or not this is true, there is ample evidence to suggest

24 P1145-4 (DC) TD 5008, 7 January 1965.

25 P1145-2 TD 5012 (DC), 6 May 1965.

26 P 1810-11 TD 7163 (DC),15 June 1967-Memorandum to Cabinet from Gen Allard (CDS) to the Minister of National Defence on the Canadian Forces Ensign. 
that he was receiving this advice from his staff. What is unclear are the positions at this time of the CP (Vice-Admiral Dyer) and the CDS (then Air Chief Marshal Frank Miller) - certainly Dyer as a naval officer should have been well aware of the international significance of a distinctive naval ensign to differentiate Canadian warships from other Canadian flagged vessels, but as $\mathrm{CP}$ he was at a disadvantage without direct naval staff support to answer the observations of Army and Air Force officers not familiar with the issue but responsible for the file. Moreover, while no hard evidence exists to suggest that the minister allowed his personal opinion to influence professional advice, it is interesting to see in DGA's recommendation to the CP in May 1965 the opinion that "integration (or unification) of the Services has not proceeded far enough to warrant an attempt to produce a single ensign." 27 Given that unification of the Canadian Armed Forces would not happen for another three years, in $1968,{ }^{28}$ one can detect an element of "touting the party-line" by CP staff.

Simply put, had the navy wished to maintain the established practice of having a separate naval ensign to distinguish commissioned Canadian warships from other Canadian flagged vessels, then appropriate naval staff action should have been forthcoming in 1965. The fact that it did not happen should not be misinterpreted as a lack of resolve to have a separate naval ensign. Rather it is a testament to the tumultuous state of affairs that existed at the time, as the Canadian Armed Forces were in the midst of the changes resulting from integration (Bill C90) and there was effectively no naval staff to initiate and push a distinctive Canadian naval ensign initiative. Moreover, given the acrimonious feelings of the nation at the time, vis-à-vis the "Great Flag Debate," it was a sensitive subject that would have required extraordinary efforts to be successful. ${ }^{29}$ Thus it becomes clear that within CFHQ there was no appetite or mechanism to pursue a distinctive naval ensign, as it was not fully understood by tri-services staffs and would have likely been seen as yet another challenge by the Navy to integration and unification, which were of great personal interest to the minister.

So like a great many things Canadian, it would appear that while Cabinet envisioned the requirement for a separate ensign for the armed services in 1964, there was no specific decision to have, or not to have, a distinctive Canadian naval ensign.

\section{5 to 2011 - The quest for a Canadian naval ensign}

Development of a Canadianized naval ensign did not come to pass in 1965 due to the overriding priorities for the elimination of the old service identities by the minister.

27 P1145-2 TD 5012 (DC), 6 May 1965.

28 Bill C-243 The Canadian Forces Re-Organization Act was passed in April 1967 and became law on 1 February 1968. "Unification is the end objective of a logical and evolutionary progression. Although integration and unification are sometimes regarded as alternatives, and inherently different, they are, in fact, merely different stages in the same process. Integration was actually the term applied to the first stages of the unification of the Canadian Armed Forces," the Hon. Paul T. Hellyer statement in House of Commons during 27th Parliament.

29 Rick Archbold, I Stand For Canada, The Story of the Maple Leaf Flag (Toronto: MacFarlane, Walter \& Ross, 2002), Chapter 1, "Identity Crisis". 
Moreover, no functioning naval staff existed subsequent to the integration of the Canadian Armed Forces in April 1964 to articulate the case for the legal requirement for an identifiable ensign complementary to the new maple leaf national flag after February 1965. Instead, what did arise in 1968 were a Canadian Forces ensign and a distinctive Canadian Naval Jack.

In March 1967, the CDS (now General Jean V. Allard) wrote Minister Hellyer with regards to "frequent and recurring request[s] from serving members for distinctive military flags." Drawing attention to the "particular controversies that arose at the time of the retirement of the white ensign," he noted that, while the navy "almost unanimously accepted" the new Canadian flag flying at the ensign staff in place of one that had really been seen as a British symbol, "the flag most sorely missed... was the [Blue] Naval Jack... the only really unique symbol used by the RCN." His firm conviction was that there was a requirement for a naval jack. Moreover, as the design of a new Canadian Forces ensign was well in progress, the CDS stated that it had become evident that the Canadian Forces ensign could not receive easy acceptance if used as a jack and he had promised the Navy they would one day have a naval jack. ${ }^{30}$

The Commander Maritime Command, Rear-Admiral J.C. "Scruffy" O'Brien (a communications specialist), spearheaded the naval jack initiative, by adopting the design of the Canadian Forces ensign but replacing the armed forces badge with elements of the Maritime Command badge superimposed with a naval crown in the fly. Notwithstanding earlier comment to the effect that the minister "was not completely satisfied that there was, in fact, a requirement for a naval jack," ${ }^{31}$ the minister's reaction to the naval jack design was reported to be favourable. ${ }^{32}$ The naval jack proposal was included with the Canadian Forces ensign submission in the draft memorandum to Cabinet on 15 June 1967. It was on this memo from the CDS that Minister Hellyer penned a minute directing the paragraph on the naval jack be re-written to "treat the jack independently rather than in the ensign family." ${ }^{33}$ The memorandum to Cabinet was subsequently re-drafted to separate the Canadian Forces ensign from the naval jack, which was then forwarded to Cabinet in July 1967, referencing the 23 December 1964 Cabinet direction for the minister to submit designs for ensigns based on the new Canadian flag. ${ }^{34}$ Cabinet accepted the requirement for a Canadian Forces ensign, but not the requirement for a naval jack. The specific issue of a naval jack had to be resubmitted in January 1968 by

30 P1810-11 (DGA) P1145-4 13 March 1967-memorandum from CDS to MND on Canadian Forces flags, ensigns and pennants.

31 P1810-11 (SEC CP-2), 3 May 1967, Extract from 216 th Meeting of Defence Council on 1 May 1967-Canadian Forces ensign and pennants.

32 P1060-1,12 May 1967, Memorandum from the CP (Air Marshall Reyno) to the CDS "Flags and pennants - ship's jack." It should be noted that by this time VAdm Dyer had retired and the new principle naval adviser was the comptroller-general of the CAF, VAdm Ralph Hennessy.

33 P1810-11 TD 7163 (DC), 15 June 1967, Memorandum from CDS to MND "Memorandum to Cabinet Canadian Armed Forces ensign." 
the new MND (the Honourable Léo Cadieux). ${ }^{35}$

On 1 February 1968, Cabinet authorized the Canadian Forces Ensign as well as "the adoption of a proposed Naval Jack" for wear by commissioned ships of the Canadian Forces (HMC ships). ${ }^{36}$ Both the Canadian Armed Forces ensign and the Canadian Armed Forces naval jack were announced in the



Illustration 12: Canadian Armed Forces ensign as of 13 April 1968.

Canada Gazette on 13 April 1968. The naval jack is described as "A white flag, of proportions two by length and one by width, containing in its canton the National Flag of Canada and, centered on the fly, a foul anchor, surmounted by an eagle volant affrontee with head lowered to the sinister; all ensigned with a naval crown." ${ }^{37}$ CF ceremonial regulations direct: "that the Canadian Naval Jack, which is also the Maritime Command Flag... shall be worn at the jack staff or bow of a vessel; the Naval Jack on HMC ships. ${ }^{.38}$

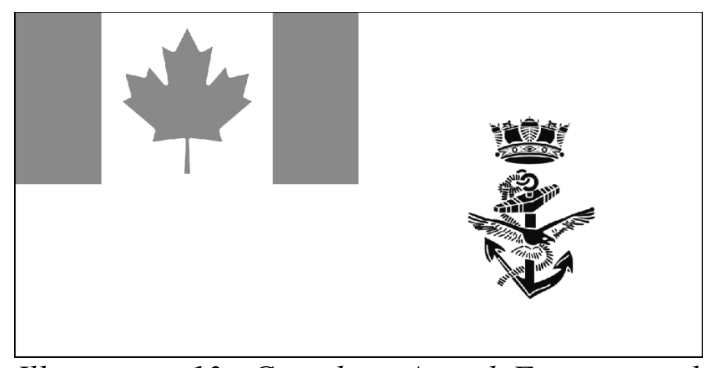

Illustration 13: Canadian Armed Forces naval jack as of 13 April 1968. Crown and anchor are dark blue, the maple leaf flag is red.
The issue of a distinctive Canadian naval ensign was taken up again in 1984 during the lead up to the $75^{\text {th }}$ anniversary of the founding of the Canadian Naval Service in 1985. Supported by a now reconstituted Maritime Command (Naval) Staff, the Commander of Maritime Command (Vice-Admiral James Wood) proposed that "the Canadian Naval Jack be approved as the Maritime Command Flag... [to] be flown in HMC ships at sea
cupied by the National Flag... [and] the and in harbour in the position currently occupied by the National Flag... [and] the National Flag be flown as the Naval Jack." ${ }^{39}$ The CDS (General Gérard Thériault) had misgivings concerning the propriety of displacing the national flag as the ensign in HMC ships and the director of ceremonial (DC) drafted the response accordingly. ${ }^{40}$ On 5 February 1985, the CDS agreed to "adopting the Naval Jack as the Maritime Command Flag on land, but did not concur with the proposal to change the position on CF ships of

35 P1145-18 TD 8018 (DGPS), 18 January 1968, Memorandum to Cabinet-Distinctive Flags for the Canadian Armed Forces.

36 Record of Cabinet decision - meeting of February 1st, 1968, 8 February 1968.

37 Canada Gazette-Part 1,13 April 1968.

38 A-AD-200-000/AG-000 pg 4-3-4.

39 MARC:1150-9 (COMD), 23 November 1984.

40 1145-0096-1 TD 4347 (DC), 11 February 1985. 
the current ship's ensign (the National Flag) and the Naval Jack." ${ }^{41}$ Separately it was noted that, because the "Naval Jack was approved by Governor-in-Council for flying on ships only, the same authority is required to extend the use of the flag to land units as the Maritime Command Flag." ${ }^{42}$ Accordingly, on 2 May 1985 the Governor-General approved the use of "the Canadian Armed Forces Naval Jack as the Maritime Command Flag." ${ }^{43}$

In addition to the changes to the ensign and jack, the white (commissioning) pennant also has changed over the years. Initially, HMC ships wore a British style white pennant (with a cross of Saint George) from 1911 until eventually replaced, without ceremony, by a Canadianized variant starting in the 1980s. There was a little-known initiative in 1967 to develop a variant of the white pennant for HMC ships utilizing the new Canadian flag, but it did not progress because of concerns that the proposal (pictured below) would "result in a diminution of the national flag to an undesirable degree." 44

The current Canadianized variant of the white pennant was adopted by HMC ships, commencing in the 1980s, by simply replacing the previous variant as stocks were exhausted, at the end of that decade.

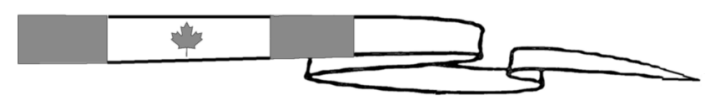

Illustration 14: Proposed revised white (commissioning) pennant, late 1967. (Red maple leaf and bands on white.)

In summary, because of actions surrounding the adoption of a national flag in 1965, complicated by the simultaneous reorganization of the Canadian Forces in 196468, a suit of colours worn by Her Majesty's Canadian ships in commission, between 1968 and 2013, comprised the maple leaf national flag (as an ensign), the white CAF naval jack and a Canadianized white (commissioning) pennant.

41 CDS letter to Commander Maritime Command, 5 February 1985.

42 1145-0091-1 TD 4347A (DC3), 9 Apr 85, Briefing Note to ADM (Per) by director of ceremonial on the Maritime Command flag.

43 P.C. 1985-1487, 2 May 1985. Anecdotally, this was also the same period when the Mulroney Conservative government had announced a return to traditional uniform colours for the Canadian Forces (later referred to as the Distinctive Environmental Uniform (DEU)). The CDS (then Gen Thériault), a noted "proponent of the unification of the military of Canada," was not in favour of any uniform change, however, when directed by Government, he favoured an absolute minimalist approach of using the current CF pattern uniform in three environmental colours. This became the source of significant debate between the CDS and the commander, Maritime Command (then VAdm Wood), who was a strong proponent of a more traditional naval double breasted uniform - the CDS eventually agreed to a double breasted naval tunic for naval personnel. The subject of the "executive curl" rank insignia for naval officers was also brought up at this time but was considered to be too much and the price of victory for a distinctive naval tunic (challenge to the principles of unification and common rank insignia). Similarly, and also anecdotally, Gen Thériault considered the Maritime Command flag "insufficiently distinctively Canadian" to qualify for use as an ensign. 


\section{The 2011 Naval Ensign Initiative}

On 20 September 2011, the commander Royal Canadian Navy (Vice-Admiral Paul Maddison) wrote to the CDS requesting the restoration of the "Canadian White Ensign."45 As a physical descriptor of the flag itself the term is quite correct; however, perhaps a better term would have been "Canadian Naval Ensign" as the term "White Ensign" is, as we have seen, for good reason automatically associated with Britain's Royal Navy.

Citing the positive recognition the navy had received from the restoration of the executive curl in 2010 and the historic "Royal" prefix in 2011, the commander RCN saw an "opportunity to redress the one remaining significant symbol of our pre-unification naval heritage," that being "Canada is the only [major] Commonwealth nation that does not fly a white ensign at the stern of our warships." 46 Moreover, he stated that the recent Canadian Naval Centennial had generated much discussion on this issue, with the most practicable option being adoption of the present naval jack as a Canadian naval ensign. Seeking CDS concurrence, his argument was that it would be "quite expedient and costeffective, in that it would simply reverse the present order of wear, there would be no need to request a new design from the Heraldic Authority, and the flags are both already available in the supply system, making the initiative effectively cost-neutral."47

On 27 September 2011 the CDS (General Walter Natynczyk) supported the Commander RCN's request and forwarded it to the Minister of National Defence (MND, the Honourable Peter MacKay) recommending "the adoption of a distinctive Canadian White Ensign" in an "expeditious and procedurally efficient fashion by simply reversing the present order of wear of the flags." 48

Minister MacKay subsequently endorsed the CDS's request and wrote to the Minister of Canadian Heritage and Official Languages (MCHOL, the Honourable James Moore) on 25 October 2011 requesting favourable consideration of the CDS's request. ${ }^{49}$ Minister Moore responded to the MND on 23 March 2012, that the "dressing of Her Majesty's Canadian Ships is the responsibility of the Department of National Defence," 50 registering no objections but effectively turning the issue back to DND for

45 3371-1325-1 (CMS/RDIMS \#220069), 20 September 2011.

46 A subsequent review of Commonwealth nations showed that of a total of 54 Commonwealth nations, 47 have some form of maritime security force, of which 32 have a distinctive naval ensign. Of the Commonwealth nations possessing a self-styled Navy, Canada was one of six that did not have a distinctive naval ensign. Given the relative size of the RCN in comparison with other Commonwealth navies, Canada was noticeably different.

47 3371-1325-1 (CMS/RDIMS \#220069), 20 September 2011.

48 Request for Restoration of a Canadian Naval White Ensign, CDS Letter to MND, 27 September 2011.

49 Letter from Minister of National Defence to Minister of Canadian Heritage and Official Languages, 25 October 2011.

50 Letter from Minister of Canadian Heritage and Official Languages to Minister of National Defence, 23 March 2012. 
implementation.

As a result of this ministerial level correspondence, a working group (WG) chaired by the Deputy Commander RCN (Rear-Admiral Mark Norman) met initially on 15 May 2012 to determine the way ahead. The WG discussed a number of issues, including historical background, legal, logistics, strategic communications, announcement timings and messaging. On 24 July 2012, the WG met to discuss legal advice recently obtained from the Deputy Judge Advocate General (DJAG).$^{51}$ As a result of this opinion, and subsequent staff level discussions, Treasury Board Secretariat (TBS) officials indicated that a Governor in Council (GIC) decision was required to allow HMC ships to fly a distinctive Canadian Naval Ensign different from, but respectful of, the national (maple leaf) flag.

At that point, in a review of the history surrounding previous attempts to establish a distinctive Canadian Naval Ensign it had became clear that:

- the decision to change the ensign and jack flown by HMC ships was outside the authority of the Minister of National Defence alone (it required a Governor in Council mandate) and therefore, any proposal must not only have the support of the CDS and the MND, and ultimately the Privy Council Office (PCO) as well; and

- all previous proposals to adopt a distinctive Canadian Naval Ensign had failed to address the key point under international law that a naval ensign is a distinguishing flag of a warship in commission that differentiates it from other nationally flagged vessels.

In short, notwithstanding the convoluted post-1965 staff actions regarding a Canadian Naval Ensign, there was nothing that precluded the Government of Canada from introducing a distinctive naval ensign, to be worn by Canadian warships, should it decide to do so. What was different in the circumstances from the summer of 2011 was that, for the first time since the adoption of the maple leaf flag in 1965, the leadership of the Navy, the Canadian Forces, and the Government of Canada all were in agreement about the merit of a distinct Canadian Naval Ensign.

Staffing then proceeded to obtain the necessary formal approvals, with the objective of an announcement of a distinctive Canadian Naval Ensign by the Government of Canada in conjunction with the annual Battle of the Atlantic commemoration on 5 May 2013. The rationale behind the impetus for a change to a distinctive Canadian Naval Ensign was defined by the following themes:

- A distinctive naval ensign, which incorporates the national flag, clearly distinguishes Canadian warships from other Canadian flagged vessels.

- A distinctive naval ensign highlights the special status that warships have in international law.

- A distinctive naval ensign underscores the unique roles, responsibilities, liabilities and powers of a ship's company as members of the Canadian Armed Forces.

51 0160-1-06537-03-0004 (DJAG Reg Svc), Legal Advice, The Restoration of a Standard Commonwealth Naval Custom-The Royal Canadian Navy Flag, 27 June 2012. 
- A distinctive naval ensign promotes and strengthens Canadian naval identity.

On 25 April 2013, the Governor-General "renamed the Canadian Armed Forces Naval Jack as the Canadian Naval Ensign" and approved "the Canadian Naval Ensign for use by the Canadian Forces as directed by the Minister of National Defence or his or her delegate." ${ }^{52}$ This decision was announced by the Minister of National Defence on 2 May 2013 followed up by a formal notice in the Canada Gazette on 8 May 2013. ${ }^{53}$

At Colours (08:00 local time) on Sunday, 5 May 2013-Battle of the Atlantic Sunday-commencing with HMCS Toronto forward deployed to the Arabian Sea, the Canadian Naval Ensign was hoisted by all HMC ships, Naval Reserve Divisions and designated non-commissioned patrol craft and tenders. Concurrently, in keeping with long-standing Commonwealth practice, the national flag became the new naval jack to be worn by commissioned HMC ships. ${ }^{54}$

Thus the transition to a distinctly Canadian Naval Ensign had come full circle from Lord Grey's first attempt to Canadianize the Royal Navy White Ensign in 1911. The result is a Suit of Colours that is most uniquely Canadian, whilst simultaneously in keeping with our Commonwealth heritage.

\section{A Suit of Colours for HMC ships—5 May 2013}

The new suit of colours worn by Her Majesty's Canadian ships in commission now comprises the white Canadian naval ensign, the Canadian national flag as the naval jack and a Canadianized white (commissioning) pennant.
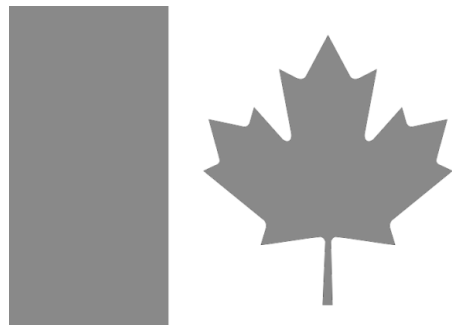

Illustration 15: Canadian naval jack. Red on white.

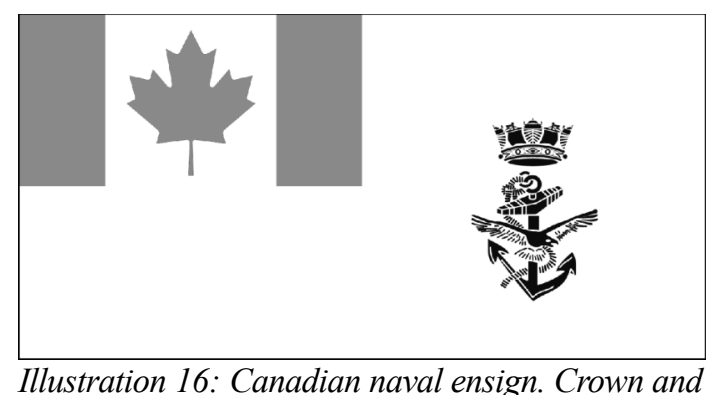

Illustration 16: Canadian naval ensign. Crown and anchor are dark blue, the maple leafflag is red.

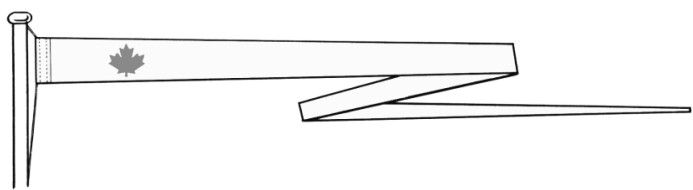

Illustration 17: White (commissioning) pennant. Red maple leaf on white.

52 P.C.2013-436, 25 April 2013

53 Canada Gazette Part II, vol. 147, no.10 TR/2013-51, 9 May 2013.

54 CANFORGEN 083/13 RCN 020/13 021912Z MAY 13 and NAVGEN 019/13 021910Z MAY 13. 


\section{A Distinctive naval ensign: some misconceptions and the facts}

\section{A separate naval ensign is not required}

The essence of a naval ensign is to indicate that the ship flying it is "a ship of war in commission" representing the authority of that particular nation. It is important to note that ships of war are not usually subject to the same rules and regulations as other nationally registered vessels; for example the decision to exempt HMC ships from the Canada Shipping Act underscores the unique status of Canadian warships under Canadian

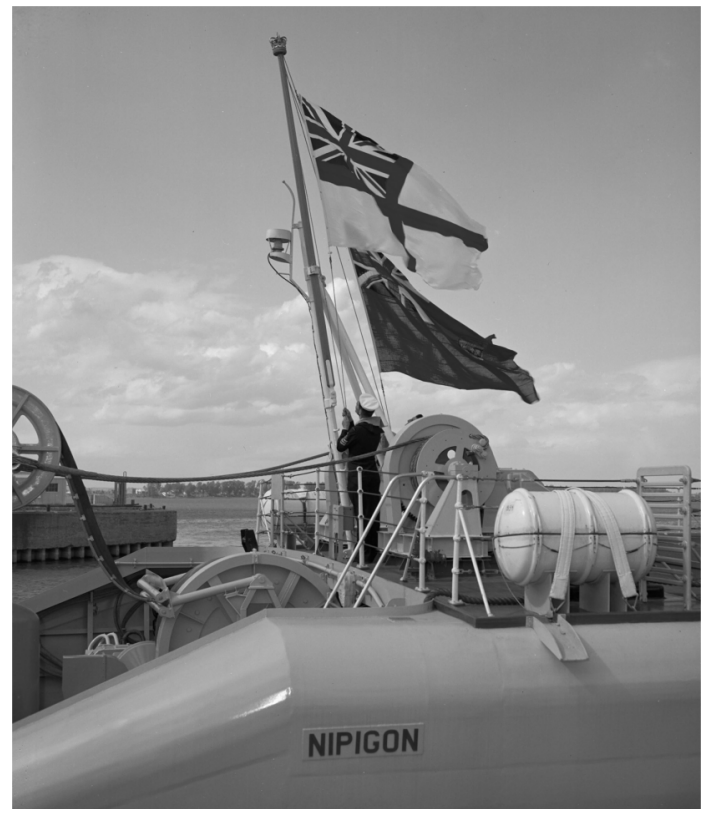

Illustration 18: The national flag (red ensign) is lowered while the naval (white) ensign is hoisted at the moment of commissioning of HMCS Nipigon on 30 May 1964. (RCN photo EKS-1557). law. Rather, like members of the armed forces as a whole, a warship is subject to different and often greater national regulation. Moreover, it is accepted international practice to formally identify the status of different nationally flagged vessels by the use of distinctive national ensigns. Note, this argument also applies to the wearing of a distinctive government ensign for non-warships in government service (i.e., Canadian Forces auxiliary vessels).

In Canada, prior to the adoption of the maple leaf national flag in 1965 , during post-build trials new construction warships flew the Canadian red ensign until such time as they were formally commissioned as HMC ships. Upon commissioning, the Canadian red ensign (then national flag) was hauled down as the naval (white) ensign was hoisted, and the commissioning pennant broken, during the commissioning ceremony.

\section{It is a British flag}

There can be a misconception that a white naval ensign, regardless of design, is a return to a British flag. While not true, the misconception is understandable because virtually every modern navy in the world can trace its roots back to the British Royal Navy, and many have adopted varying degrees of British customs, including distinct flags for commissioned warships, merchant ships and government ships (for example, that also is why most navies wear blue uniforms). The British Royal Navy is seen as the first modern navy and it was the navy of choice for many aspiring nations to go to for assistance in developing their national navies in the $18^{\text {th }}, 19^{\text {th }}$ and $20^{\text {th }}$ centuries. So it is completely understandable to see, in addition to former colonies, some baseline British naval customs resident, for example, in the Russian Navy, the Japanese Maritime Self Defence Force and the German Navy. 


\section{It is a Commonwealth flag}

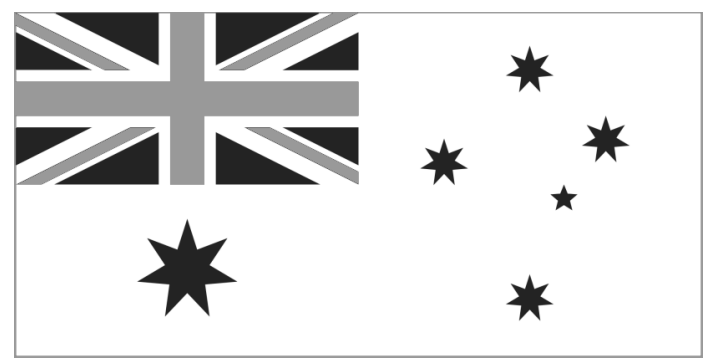

Illustration 19: Australian Naval Ensign as of 1967. The Southern Cross constellation is dark blue.



Illustration 20: Indian Naval Ensign as of 2004. Red cross of St. George on white with national flag in upper hoist canton.
Canada is a very prominent member of the Commonwealth (we are the second largest financial contributor after Great Britain), and after Great Britain, India and Australia, we probably have the next largest Navy. The Commonwealth today consists of 54 nations (one is currently suspended) of which 47 have some form of maritime security force (some of which are very small) and many that no longer have Queen Elizabeth II as their Head of State (for example, India, Pakistan, and South Africa). Canada until this recent initiative was one of only six Commonwealth nations with a self-styled navy but without a distinct naval ensign, the others being Cameroon, Cyprus, Mozambique, Namibia, and The Gambia. So is it a Commonwealth flag? Not exactly, but regardless of size of their maritime security force, over two-thirds of Commonwealth nations have a distinctive naval ensign for their warships; Canada, given the relative size of her navy, was a most notable exception.

\section{Republics don't have naval ensigns}

Republics tend not to use separate naval ensigns (examples in Appendix 1), however, as with everything to do with national flags that is not strictly true. Some republics, for example Russia and Ukraine, have very distinctive naval ensigns that bear absolutely no resemblance to the national flag. Conversely, republics like Germany have a distinctive naval ensign that is an obvious derivative of the national flag. So, contrary to popular thought, a number of republics (examples in Appendix 2) do have a distinctive naval ensign.

This aspect of the issue is complicated by the fact that the largest navy in the world, and our closest neighbour, is a republic that does not have a separate naval ensign

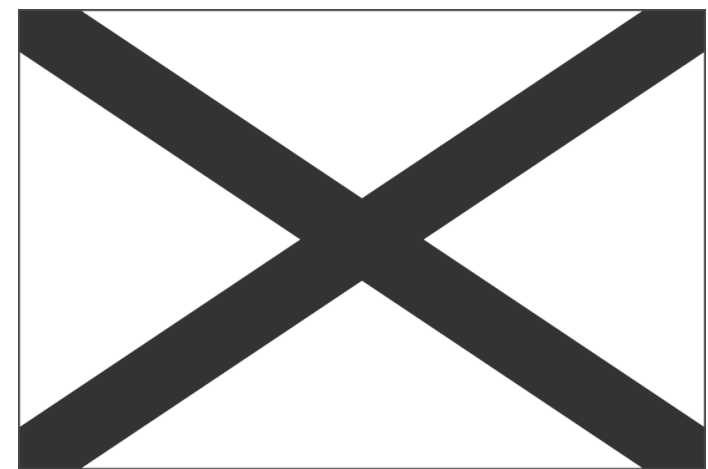

Illustration 21: The Russian naval ensign, reintroduced in 1992. Blue cross of St. Andrew on white. 
distinguishing warships from other U.S.flagged vessels. The United States of America flies its national flag as its ensign.

It should be noted, however, that this is a confusing example, as it is little appreciated the "The Stars and Stripes" began its existence as the ensign for the fledgling U.S. fleet, as adopted by the Second Continental Congress on 14 June 1777: "The 1777 resolution was most probably meant to define a naval ensign.

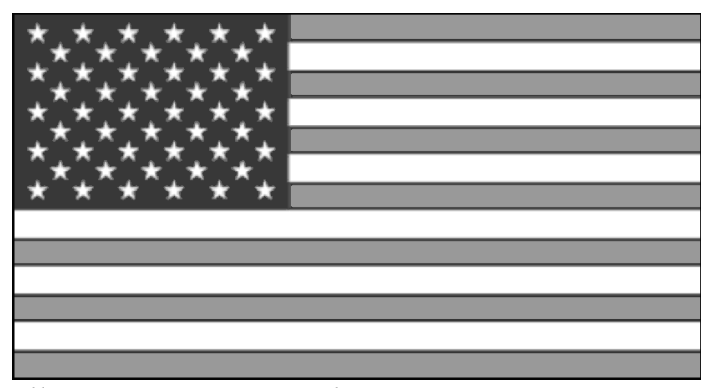

Illustration 23: United States Navy ensign.

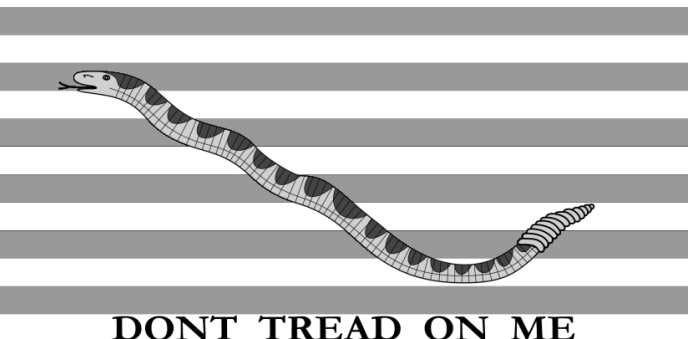

\section{DONT TREAD ON ME}

Illustration 24: United States Navy jack as of 2002.

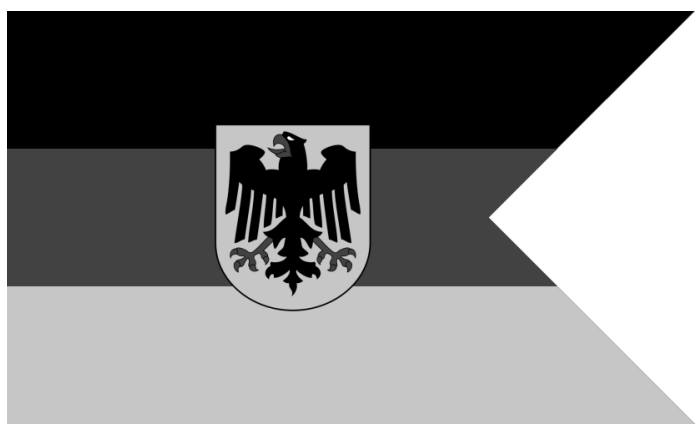

Illustration 22: The German naval ensign. Black, over red, over yellow.

In the late $18^{\text {th }}$ century, the notion of national flag did not yet exist, or was only nascent. The flag resolution appears between other resolutions from the Marine Committee." 55

Indeed, in this respect, the US national flag more closely parallels the Canadian red ensign, which became recognized as our national flag through its ubiquitous display on the stern of the Canadian merchant fleet, which at the end of the $19^{\text {th }}$ century was one of the largest in the world.

In continuation of this theme, it is interesting to note the USN has reintroduced another of its early flags as a jack, the so-called Gadsden "Don't Tread On Me" flag used by the Continental Marines as an early motto flag. ${ }^{56}$

\section{Appendix 1}

Some examples of countries that use their national flag as a naval ensign.

$\begin{array}{llll}\text { United States of America } & \text { France } & \text { The Netherlands } & \text { Turkey } \\ \text { Greece } & \text { Portugal } & \text { Spain } & \text { Chile }\end{array}$

55 Boleslaw Mastai and Marie-Louise D'Otrange Mastai, The Stars and the Stripes: The American Flag as Art and as History from the Birth of the Republic to the Present (New York, Knopf, 1973), p.60, referenced and quoted at: http://en.wikipedia.org/wiki /Flag_of_the_United_States\#cite_note-68, accessed 12 June 2013.

56 See http://en.wikipedia.org/wiki/Gadsden_flag, accessed 12 June 2013. 
Some examples of countries that use their national flag as a naval ensign.

Brazil

Argentina

Republic of Korea

\section{Appendix 2}

Some examples of non-Commonwealth navies with naval ensigns.

$\begin{array}{llll}\text { Germany } & \text { Sweden } & \text { Denmark } & \text { Finland } \\ \text { Japan } & \text { Russia } & \text { Ukraine } & \text { People's Republic of China } \\ \text { Bulgaria } & \text { Norway } & \text { Belgium } & \text { Democratic People's Republic of Korea }\end{array}$

Italy 